\title{
THE ROLE OF THE DIVAN CLERKS AND POLITICAL LETTERS IN THE DEVELOPMENT OF THE I. ABBASID PERIOD LITERATURE PROSE. AHMED BIN YOUSSEF'S ALHAMIS RESSALA AS AN EXAMPLE
}

\author{
Muhammet ABAZOĞLU ${ }^{1}$
}

\section{Istanbul / Türkiye \\ p. 543-556}

Received: $15 / 11 / 2021$

Accepted: 06/12/2021

Published: 01/01/2022

This article has been scanned I iThenticat No plagiarism detected

\begin{abstract}
:
Divan Scribe is a very old profession and it is said that it was one of the highest and most respected statures among worldly affairs, after the caliphate, when their positions in the state policy and judicial affairs are taken into account. Most of the time, the profession of the Divan Scribe was an important step to enter politics, as well as an important tool for reaching high positions such as Vizier. In general, Divan Scribes had a special role serving the Arab culture during the Abbasid period. Because the writing style of the Scribes had both lofty ideas and beautiful expression. As a matter of fact, as required by their statures, these people developed a dual-character expression that both emphasized the goals of the orders given from the administration and had the characteristics of Arabic rhetoric in the literal sense of the word. Their language was not a dry administrative language, on the contrary, it had brought together the requirements of the administrative language and the artistic beauties of the word. This study sheds light on the relations of the Divan Scribes with politics and the importance of this position during the Abbasid period. Again, in this study, the connection of the art of scribe with the vizier and the contributions of the scribes in service to the Arab-Islamic culture and especially in political thought are discussed despite the political crisis and troubles faced by the scribes.
\end{abstract}

Key words: Abbasid, Clerk, Divan, Ressala, Ahmed Bin Youssef.

http://dx.doi.org/10.47832/2717-8293.15.38

1 iD Dr. , Türkiye, m.abaz555@gmail.com, https://orcid.org/0000-0003-2153-3909 


\title{
BİRINNCİ ABBASİ DÖNEMİ EDEBİ NESR'İN GELIȘIMINNDE DİVAN KATİPLİĞİNINN VE SIYYASI RİSÂLELERİN ROLÜ: AHMED BİN YUSUF'UN HAMÎS RISÂAESİ ÖRNEĞİ
}

\begin{abstract}
ÖZET:
Divan kâtipliği gayet eski bir meslek olup kâtiplerin devlet politikasında ve yargı işlerinde edindikleri konumlar nazar-1 dikkate alındığında dünyalık issler arasında hilafet makamından sonra en yüksek ve saygın makamlardan biri olduğu söylenmiştir. Çoğu zaman kâtiplik mesleği siyasete girmek için önemli bir basamak olmasının yanında vezirlik gibi yüksek makamlara ulaşmak için de önemli bir araçtı. Genel olarak Abbasiler döneminde divan kâtiplerinin Arap kültürüne hizmette özel bir rolü vardı. Çünkü kâtiplerin yazım üslubu hem yüce fikirlere hem de güzel ifadelendirme özelliğine sahipti. Nitekim bu kişiler bulundukları makamın gerektirdiği üzere hem yönetim katından verilen emirlerin hedeflerini vurgulayan hem de kelimenin tam anlamiyla Arap retoriğinin özelliklerini taşıyan ve sanat yönü olan çift karaktere sahip bir ifade tarzı geliştirmişlerdi. Bu dil kuru yönetim dili olmayıp aksine yönetim dilinin gerekliliklerini ve sözün sanatsal güzelliklerini bir araya getirmiştir. Bu çalışma, Abbasiler döneminde kâtiplerin siyasetle olan ilisskilerini ve kâtiplik makamının önemini sunmaktadır. Yine bu çalışmada kâtiplik sanatının vezirlikle bağlantısı ve kâtiplerin karşılaştığ 1 siyasi kriz ve sıkıntılara rağmen Arap-İslam kültürüne hizmetteki katkıları ve özellikle de siyasi düşüncedeki katkıları ele alınmaktadır.
\end{abstract}

Anahtar Kelimeler: Abbasi, Kâtiplik, Divan, Risâle, Ahmed Bin Yusuf

\section{GİRIŞ̧}

İlk çağlardan günümüze kadar insanoğlu, etrafında ne olup bittiğine dair sürekli bir merak içerisinde olmuştur. İlk insanlar için iletişim ve haberleşme, hafıza ile sınırlıydı. Bilgiye sahip olmak ve onu korumak, haber vermek insan yaşamının vazgeçilmez gerçeğidir. İnsan hafızası tüm bilgiyi toplayacak ve koruyacak bir yapıda olmadığı için toplanan bilginin ve haberin kaydedilmesi zorunluluğu doğmuştur (Türk, 2019: 282). Abbasi dönemi boyunca süren yazışmalar aslında oldukça eski zamanlara dayanmakta olup milletler ve uygarlıklar kadar eskidir. Çünkü bu yazışmalar krallar ve diğer yöneticiler arasında bir tür iletişim ve karşı1ıklı anlaşma aracıydı. Ancak kaynaklarda geçtiği üzere başlangıçta şifahi olarak gerçekleşen iletişim; yazı araç ve gereçlerinin gelişme göstermesi, yazma ve okumayı öğrenenlerin çoğalmasıyla birlikte yazışma yoluyla nakle dönüşmüştür.

Konuşma becerisi diğer beceriler (okuma, dinleme, yazma) ile birlikte geliştirilmelidir. Konuşma, zamanla diğer beceriler (okuma, yazma, dinleme) ile gelişir (Türk, 2017: 787).

Daha sonraları da birbiri ardınca ortaya çıkan uluslar ve devletlerle birlikte yazışmalardaki yöntemler gelişme gösterirken divanlar da devlet idaresindeki önemli daireler arasından özel bir daire olarak ortaya çıkmıştır. Nitekim kâtipler ve yazışmalar için özel bir kurul ve meclis ihdas edilmiş olup saygınlık bakımından da krallar ve diğer yöneticiler ile birlikte anılır olmuşlardır. Böylece devletlerin iç ve dış ilişkilerini yürütmede kendi stratejilerini, isteklerini ve siyasetlerini dile getirebilecekleri bir iletişim sistemi kurmaları kaçınılmaz olmuştur (Beyyûd, Hüseyin, 1996, s. 13). İslam'ın yayılması ve İslam devletinin genişlemesiyle birlikte divanlar/kurullar çoğaldığı gibi yeni devletin işlerinin yürütülebilmesi için de gerekli olan uzmanlık ve görev alanlarındaki çeşitlilik artmıştır. Nihayetinde de divanlar ve bu divanlarda görev alan kişilere yetkiler verilmiş, bunlara özgü kanunlar çıkarılmış ve düzenlemeler yapılmıştır. Yapılan bu düzenlemelere Divaniye (Düzenlemeleri) terimini kullanabiliriz. İlim ehli yazı sanatkârlarında bulunması gereken özellikleri, ya da ifade araç ve gereçlerini açıklamışlardır. Abdulhamid el-Katib’in risalesi de kâtiplik kültürü alaninda derlenen ilk risaledir (el-Cehşeyârî, 1938, s. 74-79) (İbn Haldun, 2004, s. 1/431) (el-Kalkaşendî, Ty, s. 1/91).

Yazışma işi devlet sınırlarının genişlemesi, valiler ve memurların çoğalmasıyla ortaya çıkmıştır. O zamanlar devlet, çeşitli bölgelerdeki mevki ve makam sahibi valilere ve diğer memurlara devletin siyaseti ve yönetimiyle ilgili işlemleri iletme ihtiyacı duymuş ve mektuplar da bu işi için en uygun araç olmuştur. Sonuçta mektuplaşmaya/yazışmaya özgü bir divan kurulmuş, divan başkanına da makamı itibarıla günümüzdeki bakanlık 
makamına denk bir mevki tahsis edilmiştir. Bunlara ek olarak bu divanın memurları ve astları bulunmaktaydı ve her biri de divandaki konumunun kapsamına göre çalışmaktaydı (Ferrûh, Ömer, 1981, s. 1/374).

$\mathrm{Bu}$ makamın önemine uygun olarak orada çalışan kişinin de nitelikli ve bilgi birikimi açısından yüksek kapasitede olması gerekiyor. İbni Esir gramerci, hukukçu veya kelamcılardan farklı olarak kâtibin bütün ilimlerle alakadar olması gerektiğine dikkat çekmektedir. Buna göre kâtipler Arapçaya, dilbilimine, Arap atasözlerine, Arap tarihine ve yine devlet başkanlığında, emirlikte, hisbe ve benzeri teşekküllerde yer alabilmek için gerekli olan mülki idare bilgisine sahip olmalıdır. Ayrıca Kur'an ve hadis ezberine aşina olması gerektiğini belirttikten sonra sözü şöylece bağlamaktadır: "Toplu olarak söylemek gerekirse bu sanata teşebbüs eden kişi bütün sanat dallarını bilmeye ihtiyaç duyar. Öyle ki kadınların arasında ağıt yakan kadının, gelinin duvağını yapan kadın berberinin ve pazarda mal yığınının başında tellallık yapan adamın bile ne dediğini bilmelidir (İbnu'l-Esîr D. e.-F., Ty, s. 1/4-6).

Öyleyse kâtiplik makamına ulaşmak pek kolay olmayıp kişinin ansiklopedik bilgisi ve belge bilgisinin de olması, bilgilerinin çok yönlü olması ve hayli kültürlü olması gerekir. Bazen kâtip inceden inceye bir sınavdan geçirilir. Bu sınav üzerinden edebi ve fikri birikimi neyse ortaya çıkar. İşte bu noktada I. Abbasi döneminde kâtipte olması beklenilen geniş kültür, sağduyu, ince zevklilik, yumuşaklık, sabır, zekâ, işleri yürütme, hazır cevaplık, muhataplıkta zarafet, kalpleri ve kulakları cezp ederek devlet ricalinin gönlünü kazanan ve onların akıl düzeylerine baskın gelen konuşmadaki retorik ölçülerine dair birçok delil ve yazılı belge bulunmaktadır (Dayf, 1966, s. 485).

Buradaki büyük önem eski bilginler tarafından fark edilmiş ve bu makamı güzel bir şekilde nitelemişlerdir. Nitekim kâtiplik sanatı ile devlet işlerini kuvvetli bir bağ bulunmaktadır. Çünkü kâtiplerin divanında üye olarak bulunan ve yazışmalardaki kompozisyonu ayarlayan bir kişinin kralların yanındaki konumu her zaman yüksek ve itibarı da yüce olmuştur. Nitekim krallar bu kişilere sırlarını açmışlar, onlar da bu sırları saklamışlar ve erkânı arasında en yetkililerin bile bilmediklerine vakıf olmuşlardır. Buna göre sultanın yanında kâtipten daha seçkin birisi bulunmamaktadır. Zira kâtip, sultanın yanına ilk girip son çıkan kişi olup aynı zamanda sultanın kendisiyle fikir alış verişinde bulunduğu gibi sultanın sırdaşı da olmuştur (el-Kalkaşendî, Ty, s. 1/101).

İbni Abdi Rabbih de daha önceleri önemsiz olan ve kâtiplik sayesinde yükselen ve isimleri duyulan kişileri şöyle saymaktadır: "Çağımızda onlardan bazıları: Yakub b. Davud, Yahya b. Halid el-Bermeki, İbnu'l-Mukaffa', el-Fadl b. Sehl ve onun kardeşi Hasan, Ahmed b. Yusuf, Muhammed b. Abdulmelik ez-Zeyyat ve benzerleri" diyerek dile getirmiştir (İbnu Abdi Rabbih, 1983, s. 4/282).

\section{Abbasiler Dönemi Edebi Risale Çeşitleri}

Sanatsal özelliğe sahip risalelerde bütün çeşitleri bakımından gayet açık bir ilerleme gözlemlenmiştir. Bu alandaki düzyazı sanatı içerik ve üslupta aynı düzeyde gelişme göstermiş, içerik ve yönelimdeki çeşitlilikte örnek gösterilir olmuştur. Abbasi toplumunun gelişimi bu sanatın ortaya çıkmasına yardımcı olmuştur. Şüphesiz aynı toplum içerisinde çeşitli edebi, sosyal ve siyasi konulara katılan çok sayıda yazarın bulunması da bunun kanıtıdır. İbnu'l-Mukaffa', Sehl b. Harun, Abdulhamid el-Katib, Amr b. Mes'-ade ve benzerleri gibi yazarlar bu gelişime örnek olarak gösterilebilir. Böylece Abbasi dönemi risaleleri büyük ilerleme kaydederek Abbasi nesir sanatının en önemli eserleri arasında yer almıştır. Bu çalışmada da edebi risaleler ve dostluk (ihvâni) risalelerinin kısa bir tanitımindan sonra siyasi risaleler konusu ve özellikle de Me'mun'un veziri Ahmed b. Yusuf'un "Risaletü'l-Hamîs"i (Perşembe Yazıları) ele alınıp değerlendirilecektir.

Abbasi döneminde çok çeşitli gerekçelerle çeşitli risaleler yazılmış ve zamanla gelişme göstererek kadim Arap şiirinin dile getirdiği birçok konuya da girilmiştir. Bu da bu alandaki ifade yollarının çeşitliliğine işaret etmektedir. Bu alan ise şiirin ve risale yazma sanatının da ötesinde arı duru bir edebiyat alanını kapsamakta ve kendince önemli konuları dile getirmektedir. Bu gelişmenin sonucu olarak düzyazı sanatı ortaya çıkmıştır. Edebi risale yazarları da bu gelişime uygun olarak yenilemeye yönelmişler, daha önceki geleneksel risale formu dışına çıkarak yeni üsluplar geliştirmişlerdir. Dolayısıyla dostluk ve divan risaleleri de hem şekil hem de içerik bakımlarından geleneksel formunun dışına çıkarılmıştır. Bu risale türlerine bakıldığında; hem divan ve hem de dostluk risaleleri içerisinde edebi nitelik, 
düzyazı sanatkarlığı, yazı ve hitabet özelliklerini taşıdığından dolayı edebi risale grubuna girdikleri görülmektedir (Zeydân, Ty, s. 2/268).

\section{Dostluk Risaleleri:}

$\mathrm{Bu}$ risale türü kişilerin duygu ve düşüncelerini, arzularını ve korkularını arz eden risalelerdir. Bunlar övgü, sitem, özür, acındırma, kutlama, ağıt ve taziye içerikli olabilmektedir. Bu konular önceleri şiir yoluyla dile getirilirken Abbasi döneminde şiirsel bir nesir tarzıyla dile getirilir olmuştur. Bunun sebebi de düzyazıda seçkin bir yazar tabakasının ortaya çıkmasıdır. Bu yazar tabakası gayet güzel yazmakta ve geniş bir kültürden yararlanmakta idiler. Buradan itibaren geniş bir kitle tarafından temsil edilen medeni bir model haline gelmişlerdir. Böylece söz ya da konuşma, Arapların geçmişte sahip olduğu kabalık ve göçebelik görüntülerinin aksine olarak başkalarına hitap ederken sahibinin medeni imajını yansıtan daha dikkatli ve hassas bir düzeye ulaşmıștır (Dayf, 1966, s. 491).

\section{Siyasi Risaleler:}

Bunlar divan risaleleri olarak da bilinmektedir. Çünkü bu risaleler yöneticiler, valiler ve emirlerin divanlarından çıkmaktadır. Araplar bu risale türünü İslam'ın ilk döneminden beri bilmektedirler. Hatta Kalkaşendi, bu risale türünün ilk olarak Peygamber (sav) döneminde ortaya çıktığı görüşünü belirtirken şöyle demektedir: "Bil ki bu divan İslam döneminde tesis edilen ilk divandır. Nitekim Peygamber (sav) emirleriyle, ileri bölük komutanlarıyla karşılıklı olarak yazışmaktaydı. Yine yakın bölgedeki toprakların krallarıyla da yazışarak onları İslam'a davet etmekte ve elçileriyle bu krallara yazılı mesajlar göndermekteydi” (el-Kalkaşendî, Ty, s. 1/91). Aynı şekilde Peygamber (sav) Müslümanları okuma ve yazmayı öğrenmeye teşvik etmiş hatta yazıyı her bir fert için zorunlu görmüştür. $\mathrm{Bu}$ durumun en belirgin dinamiği ve bütün bölgelerde yaygınlık kazanmasının gerekçesi de bir devletin ilişkilerini, iç ve dış bağlantılarını anlatmasının ancak yazışmalar yoluyla mümkün olmasıydı. İsste böylece Peygamberin İslam devletini kurması, bir yazışma sisteminin de kurulmasinı gerekli kılmaktaydı (Nassâr, 2002, s. 38).

Divan risalelerinin içeriğine baktığımızda devletin idari, siyasi ve mali işlerini konu edinmesinin yanında anlaşmalara, geleneklere, hilafetin intikali, fetihler, biat etmeye çağrı, cihada teşvik gibi resmi ve idari yönü olan konuları da içerdiği görülür. Yazışma divanları zamanın ilerlemesi, İslam devletinin alanının genişlemesi ve siyasi olayların yeni boyutlar kazanmasıyla birlikte günümüzdeki resmi devlet dairelerindekine benzer resmi bir karakter kazanmıştır. Daha sonra da Emeviler döneminde Muaviye zamanında örgütlü görüntüsüyle ortaya çıkmıştır. Akabinde de bu risaleler Abbasilerin ilk dönemindeki büyük siyasi dönüşümün ve eş zamanlı siyasi olayların sonucunda benzersiz bir gelişme göstermiştir (Dayf, el-Fennu ve Mezâhibuhû fi'n-Nesrił-Arabî, Ty, s. 99).

\section{Devlet Yönetiminde Risalelerin Rolü ve Divan Risalelerinin Konuları}

Abbasiler dönemindeki siyasi çekişmeler boyutundan olaya baktığımızda risalelerin dahili ve harici olaylarda bariz bir rol oynadığını görürüz. Risalelerin gelişme göstermesinde siyasi gelişmelerin de etkisi olmaktaydi. Zira bu siyasi gelişmelerle birlikte devlet düzeni de gelişme göstermekte ve bu durum da risaleleri fikri-akli yönden ve diğer kültürlerle ilgili açılımlar bakımından şekillendirmekteydi. Yazılma amacı propaganda olan yüzlerce mektubun/risalenin eşlik ettiği bu olaylar arasından en öne çıkanı da Abbasi ayaklanmasıydı. Bundan sonra da Mansur'a amcası Abdullah b. Ali'nin ve Ebu Müslim elHorasani'nin başkaldırması, Muhammed en-Nefsu'z-Zekiyye ile kardeşi İbrahim'in darbe girişiminde bulunmaları ve veliahtlık konusundaki anlaşmazlık gelmektedir. Yine bu dönemde siyasi sahnede cereyan eden Emin ve Me'mun arasındaki büyük fitne, diğer ayaklanmalarla birlikte Babek ve Maziyyar ayaklanmaları da bu olaylar arasındadır (Dayf, 1966, s. 11); (et-Taberî, Ty, s. 1834); (Çelik, 2006, s. 95-106); (Bozan, 2014, s. 73-93).

Gerçekten de risaleler, kendi zamanındaki toplumun gerçeklerini yansıtmasının yanında yaşam şartlarıyla olan bağlantısı ve büyük bir tarihi değere sahip olması sebebiyle islam tarihi konuları arasında önemli bir yer tutmaktadır. Diğer taraftan bakıldığında birinci Abbasi döneminde divan risalelerinin altta verilen konular çerçevesinde ele alındığı görülür. 


\section{Abbasi Davas1 ya da Devrimi:}

Abbasi davası risalelerin sunduğu konular arasındadır. İbrahim el-İmam ve devrim propagandaciları arasında cereyan eden bu risaleler emirleri iletmek, taraftarları harekete geçirmek ve propaganda çalışmalarına dair açıklamalar yapmada önemli bir araçtı (etTaberî, Ty, s. 1444). İbrahim İmam'ın isteğiyle yazılan ve Ebu Müslim’in Horasandaki propagandayı yürüttüğünü kendi taraftarlarına haber veren şu risale de bunlardan biridir:

$$
\text { (إني قد أمرته بأمري، فاسمعو ا منه و اقبلو ا قوله، فإني قد أمرنه على خر اسان وما غلب عليه بعد ذلك) }
$$

"Ben işimin yürütülmesini ona buyurdum. Onu dinleyin ve sözünü yerine getirin. Ben Horasan'a onu memur kıldım. Bundan sonra kimse onun önüne geçemez" (Safvet, 1938, s. 2/476). Bu mektup Abbasi devriminin ilk aşamaları olduğu için ve o koşullara uygun olarak yazılmıştır. O dönemin tehlikeli olmasından dolayı mektupta da içerik bakımından gizlilik, dikkatli olma ve şüphe arz etmektedir ki, gözetilen amacı açıklaması ve yerine getirmesi o zaman bunu gerektiriyordu.

\section{Siyasi İç Çekişmeler:}

Siyasi risale konusunda elimize en çok ulaşan risaleler iç siyasi çekişmelerle ilgilidir. $\mathrm{Bu}$ çekişmeler en çok da Abbasilerle şu güçler arasındadır: Abbasi devriminin kendi önderleri ve propagandacıları, Ali evladından olanlar ve taraftarları, hariciler, ayaklanma ve fitne çıkarma taraftarları (Dayf, 1966, s. 26).

$\mathrm{Bu}$ konuda çok çeşitli risaleler vardır. Bunlardan Mansur ile Ebu Müslim el-Horasani arasında geçen Abdullah b. Ali konulu risalelerdir. Mansur, halifelik konusunda rakibi ve kendisinin amcası olan Abdullah b. Ali'nin üzerine yürümesi için Ebu Müslim El-Horasani'yi yönlendirdiğinde aralarında karşıllklı pek çok yazışma olmuştur. Mansur her ikisini de rakip ve güçlü figürler olarak gördüğü için hangisinin diğerini yeneceğini de umursamamaktadır. Ebu Müslim galip geldiğinde, Mansur onu öldürme emri vermişti. Bu yüzden onu bir komplonun içine çekmiş ve kısa süre sonra da onu öldürerek ondan kurtulmuştur. İşte bütün bu olanlar, aralarında gerçekleşen çeşitli yazışmaların akabinde olmuştur (Safvet, 1938, s. 3/26-30).

Yine risalelerin bu türünden olarak Mansur ile Abbasi tahtında hak iddia eden ve devlete başkaldıran Muhammed b. Abdullah (en-Nefsu'z-Zekiye) arasındaki yazışmalar da bulunmaktadır. Zira Muhammed b. Abdullah, Abbasilerin tahtı kendilerinden çaldığını ve aslında kendilerinin tahta daha layık olduğunu, kendileri olmasa devletin de olamayacağını, özellikle de bu anlamda Haşimoğullarının önde gelenlerinin kendileri olduğunu ileri sürmekteydi (et-Taberî, Ty, s. 1525). Nihayet Muhammed b. Abdullah başkaldırmış ve Mansur'un gazabına uğramamak için kaçarak gözden kaybolmaya ve güvenli bir sığınak aramaya koyulmuştu. Öte yandan da Mansur, onun nerede olduğunu araştırmakta ve aralarındaki yazışmalar aracılığıla ne yapacağını anlamaya çalışmaktaydı. Gerçekten de Mansur, istediği bilgiyi elde etmiş ve onun hali hazırda gerçekleştirmeyi planladığ başkaldırının zamanını öğrenmişti (Azimli, 2008, s. 55-74).

Mansur ve Muhammed b. Abdullah arasındaki yazışmaların, yazışma örneklerinin en güzellerinden olduğu söylenmektedir. Bu yazışmalar sadece retorik yönüyle değil aynı zamanda halifelikte hak iddia eden her iki kişinin de iddialarını ispat etmek için getirdikleri delilleri içermesi ve iddialarını delillendirme yöntemi bakımından da oldukça güzeldir. Mansur, başlattığı yazışmaları konuya delalet yönü kuvvetli olan Kur'an ayetleriyle desteklemiş ve akabinde de hem Muhammed'e hem de onun taraftarlarına güvence vermiş, kendisine bolca mal mülk vaat etmiş ve hapiste tutulan taraftarlarını salıvereceğini şu ifadelerle dile getirmiştir:

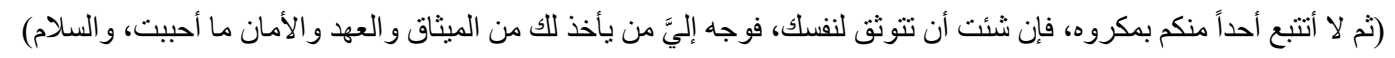

"Şu halde ben, rezil bir şekilde hiçbirinizin peşine düşmem. Kendinizi güvende hissetmek istiyorsanız sizin adınıza güvence alması için güvendiğiniz birisini bana yönlendiriniz. Selametle!" (el-Muberrid, 1997, s. 3/1488).

Muhammed de Mansur'un mektubuna Kasas suresinden bazı ayetlerle cevap vermiş, kendi dayanaklarını ve Abbasilerin hilafeti gasp yöntemini şu ifadelerle dile getirmiştir:

$$
\begin{aligned}
& \text { (و وأنا أعرض عليك من الأمان مثل الذي أعطينتي، وقد تعلم أن الحق حقنا، و إنكم إنما طلبتموه بنا، ونهضنتم فيه بشيعتنا، وأن أبانا علياً كان }
\end{aligned}
$$

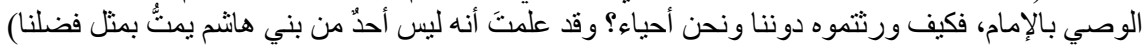

"Ben de sana, bana verdiğin gibi bir güvence sunuyorum. Hakkın bizim hakkımız olduğunu, aslında bizim sizden değil de sizin bizden bu konuda talebiniz olabileceğini ve de 
halifeliğe ancak bizim taraftarlarımızın yardımıyla geçebildiğinizi bilmektesiniz. Babamız Ali, imamın naibiydi. Pekala biz henüz hayattayken ancak biz olmaksızın ona nasıl mirasçı oldunuz? Haşimoğulları arasında sizinle akrabalığı bizimki gibi değerli olan hiç kimse yoktur..." (el-Muberrid, 1997, s. 3/1488).

Sonuçta bu yazılı münazaraların hiçbiri de yarar sağlamamıştır. Zira Mansur, kardeşinin oğlu ve veliahdı olan İsa b. Musa'yı en-Nefsu'z-Zekiyye'ye göndermiş, İsa da ona galip gelmiş ve onu öldürmüştür (İbnu'l-Esîr M. e.-Ş., 1987, s. 5/156).

\section{Diş Siyaset:}

Bir devletin diş politikasında olması gereken dış siyasete dair temel dinamikleri bu konu içerisinde görmek mümkündür. Söz konusu döneme ilişkin olarak Abbasi halifeleri ile Bizans kralları arasında yapılan bazı yazışmalarda da bunun en iyi örneğidir. Doğal olarak bu mektuplar iki devlet arasındaki ilişkileri düzenleyen yazışmaları içerdiği gibi taraflar arasında meydana gelen savaşları ve anlaşmaları içermektedir. Yine bunlara bağlı olarak İslam'a davetin iletimini yoksa da cizye ödenmesinin kabul edilmesi de bu alana dahildir (İbnu'l-Esîr M. e.-Ş., 1987, s. 5/327-333).

Bizans imparatoriçesi İrini ile Müslümanlar arasında yapılan anlaşmayı, imparatoriçeyi tahtından indirdikten sonra bozan imparator Nikeforos ve Harun Reşid arasındaki yazışmalar da bu türdendir (el-Cehşeyârî, 1938, s. 207). Harun Reşid, Nikeforos'un yazısına şöyle cevap vermektedir:

(بسم الله الرحمن الرحيم. من هارون أمير المؤمنين إلى نققور كلب الروم، قد قرأت كتابك يا ابن الكافرة، والجواب ما تراه دون أن تسمعه،

و والسلام)

“Rahman ve Rahim Allah'ın adıyla! Müminlerin emiri Harun'dan Bizans köpeği Nikeforos'a! Mektubunu okudum ey kâfirin oğlu! Cevabı ise duyduğun değil de görmüş olduğun gibidir! Selam!" (İbnu'l-Esîr M. e.-Ş., 1987, s. 5/333).

Mektuplardaki bu tarz, Me'mun'dan hediye talebinde bulunan Bizans kralı Theophilius ile Me'mun arasında yazılan mektuplarda da vardır. ${ }^{2}$ Mu'tasım'in Bizansla yaptığı yazışmalarında da aynı tarz görülmektedir. Bu mektuplar arasında, 223 h. yılında yapılan Mu'tasım'ın komuta ettiği ve Müslümanların kazandığı unutulmaz Amorion Savaşı sırasında yazılan mektuplar da vardır (et-Taberî, Ty, s. 1852). Bu yazışmada Mu'tasım tehdit ve cezalandırma üslubuna başvururken şu cevabın yazılmasını buyurmuştur:

$$
\text { (بسم الله الرحمن الرحيم، أما بعد، فقد قرأت كتابك، وفهمت خطابك، و الجو اب ما ترى لا ما تسمع، وسيعلم الكفار لمن عقبى الدار ). }
$$

"Rahman ve Rahim Allah'ın adıyla! Yazını okudum ve demek istediğini anladım! Cevabı ise duyduğun değil de görmüş olduğun gibidir! Kafirler cehennemi kimin boylayacağını görecekler!" (Safvet, 1938, s. 4/11).

Abbasi Devleti'nin hariciye yazışmalarında sert bir dilin, kuvvetli kararlılığın, düşmanı hakir görmenin ve durumlarını küçümsemenin, tehdit ve cezalandırma üslubunun ön plana çıktığını söylemek mümkündür.

\section{İdari Ve Siyasi Meseleler:}

$\mathrm{Bu}$ dönemde risalelerin ele aldığ konular pek çeşitli olmuştur. Valilerin görevlendirilmeleri, görevden alınmaları, eyalet haberleri, eyaletlerdeki durumlar, fetihler, biatlerin kabulü, güvence verilmesi, yönlendirmeler, haber iletimi için yazılan yazılar gibidir. Ayrıca devlet işlerinin yerine getirilmesi ve devlet yönetiminin düzene konulmasına ilişkin konuları da kapsar. Bütün bu işlerin her biriyle görevli kişiler olup tıpkı günümüzde olduğu gibi bağlı oldukları kurumlar/divanlar bulunmaktaydı (Dayf, 1966, s. 22).

$\mathrm{Bu}$ işlere dair bir olay olarak, Mansur'a ulaşan habere göre Hadramevt valisi çokça ava çıkmakta olunca valiye kendisini görevden aldığını haber veren şu iletiyi yazar:

$$
\begin{aligned}
& \text { ما كاك تكلتك أمك، وعدمتاك عشيرتك، ما هذه العُدة التي أعددتها للنكاية بالوحش؟ إنا إنما استكفيناك أمور المسلمين، ولم نستكفك أمور الوحش، }
\end{aligned}
$$

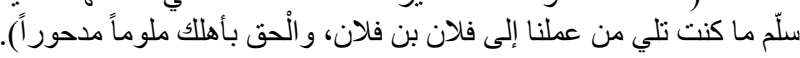

"Ölüm seni anandan ayırsın! Aşiretin seni yitirsin! Vahşi hayvanlara kıymak için yaptığın bu kadar hazırlık da neyin nesi? Biz, Müslümanların işiyle uğraşmanın sana yeterince meşguliyet çıkaracağını düşünürken vahşi hayvanları hesaba katmamıştık. Sana emanet ettiğimiz görevi falan oğlu filana teslim edesin! Sizin gibilere yerilmek ve kovulmak yaraşır!" (Safvet, 1938, s. 3/125).

\footnotetext{
${ }^{2}$ Safvet, Cemheretu Resâili'l-Arab, c. 3, s. 446.
} 
Mektuplardaki bu tarzı Abbasi halifelerinin bir kısmında da görmek mümkündür. Bunların bazılarında halifenin devlet idaresindeki katılı̆̆ını, yetki verilenlerden hesap sorulduğunu, halkın işlerinin ihmal edilmemesini, kararlı siyasete dönmek suretiyle idari yolsuzluğa karşı devlet ve yargı erkanının desteklendiğini görmekteyiz.

\section{Mektuplardaki Kurgu:}

Arap eleştirmenler ve belagatçılar yazışma sanatına çok önem vermişlerdir. Yazının hattına, yazıldığı kaleme, mürekkebe, yazının güzelliğine ve şekline ne kadar önem veriyorlarsa söylemin kolaylığı ve mananın uyumu arasındaki bağlantıya da o kadar önem vermişlerdir. Nitekim siyaset ve divan mecralarından çıkan risalelerde de en fazla özeni göstermişlerdir. "Çünkü bu mektuplar yüksek düzeyli muhataplıklarda, büyük işlerde, kamu politikasında, dünya ve dinin düzeninde etkili olan mektuplardır" (el-Kâtib, 2003, s. 342).

Mektupların kurgusuna baktığımızda üç ana biçiminin olduğunu görürüz. Bunlar: Giriş, ana konu ve sonuç bölümleridir.

\section{Giriş:}

İlk paragraf ya da başlangıç olarak da bilinir. Mesajın ne niyetle yazıldığını gösterir ve ana konusuyla bağlantılıdır (el-Kâtib, 2003, s. 38). Çünkü İbni Esir'in de dediği gibi "Konuşmanın kulağa ilk ulaşan kısmıdır. Eğer başlangıç, kendisinden sonra gelen anlama uygunsa artık onu dinlemek için yeterli sebepler vardır" (İbnu'l-Esîr D. e.-F., Ty, s. 2/224).

Giriş bölümünün bazı önemli öğeleri:

-Besmele: Allah'ın adını yüceltme ve bereketini ummak için mektuba besmele ile başlanır (el-Cehşeyârî, 1938, s. 6/222).

-Başl1k: Mektubun başında gönderen ve alıcının adı anılır. Burada asıl olan ise önce gönderenin sonra da alıcının adının yapmacıklık olmaksızın anılmasıdır (el-Kâtib, 2003, s. 330); (el-Kalkaşendî, Ty, s. 6/231). Ancak Abbasilerin ilk döneminde kâtipler, mektubu yazan iki taraftan hangisi daha üstün ise onu önce yazmaya önem vermisslerdir. Mektubu gönderen fazilet olarak daha sonra gelse bile bu böyledir. Mansur ile veliahdı olan kardeşinin oğlu İsa b. Musa arasındaki yazışmalarda da durum böyledir:

$$
\text { (بسم الله الرحمن الرحيم، لعبدالله أمير المؤمنين من عيسى بن موسى، سلام عليك با أمير المؤمنين ورحمة الله). }
$$

“Rahman ve Rahim Allah'in adiyla! Allah'ın kulu ve müminlerin emirine! İsa b. Musa'dan, ey müminlerin emiri! Allah'in selamı ve rahmeti üzerine olsun!" (Safvet, 1938, s. 3/92).

-Dua ve selam: Mektubun içeriğine işaret etmesi daha uygun görülür. İçeriğe temas ise başliktan sonra ve selamlamadan önce ara cümle olarak veya iki cümleden ibaret olarak gelir (el-Kâtib, 2003, s. 334). Selamlamaya gelince; söze onunla başlanır. Mektuplarda "esselamu aleyküm, selamun aleyküm, selamun aleyk" ifadeleriyle geçmektedir. Bazen seslenilen kişi selamdan sonra anılır. Bu da "Selam aleyk ey müminlerin emiri" örneğinde olduğu gibidir (Safvet, 1938, s. 3/92).

-Hamdele: Mektuplara Allah'a hamd ederek başlamak da güzel görülmüştür. Hamd ifadesi normalde "emmâ ba 'd" (imdi) ifadesinden önce gelmekle beraber bazen de hemen sonrasında gelebilmektedir (el-Kalkaşendî, Ty, s. 6/224). Emin'in öldürülmesinden sonra Tahir b. el-Hüseyin'in Me'mun'a yazdığ1 mektupta da bunu görmekteyiz:

(أما بعد، فالحمد لله المنعال ذي العزة والجلال والملك والسلطان، الذي إذا أراد أمراً فإنما يقول له كن فيكون، لا إله إلا هو الرحمن الرحيم).

"Emmâ ba'd! Hamd hükümranlık, mülk, celal ve izzet sahibi olan yüceler yücesi Allah'adır. O ki olmasını istediği şeye "ol" der ve olur! Rahman ve Rahim olandan başka tanr1 yoktur!" (Safvet, 1938, s. 3/308).

-Peygambere Salat: En tercih edilen uygulama, besmeleden sonra gelmesidir. Peygambere adıyla bereketli ve uğurlu olması ümit edildiğinden dolayı Peygambere salatın özel bir yeri vardır. Ancak şu da var ki Abbasilerin ilk döneminden önce nadiren de olsa divandan çıkan mektupların doğrudan Peygambere salat ile çıkarıldığı da olmaktaydı (elKâtib, 2003, s. 329). Kaynaklar, yazışmalarda Peygambere salatı uygulama geleneğine yerleştiren ilk kişinin Harun Reşid olduğu konusunda neredeyse fikir birliği içerisindedir (elCehşeyârî, 1938, s. 177); (es-Sûlî, 1922, s. 40). 
-Geçiştirme: Yani giriş kısmı atlanarak doğrudan konuya girilmesidir. Araplar bu davranışı kolaylaştırmak için hutbe ve yazışmalarda (أما بعد) "emmâ ba'd" ifadesini kullanmaktadırlar. Bunun anlamı "her neyse"dir ve kalıtsal bir ifade olarak giriş ile sözü edilen amaç arasındaki söylemi ayırma konumunda söylenmektedir. Elhamdu lillah ve duadan sonra geldiği gibi "falan oğlu filandan falan kimseye" ifadesinden sonra da gelebilmektedir (es-Sûlî, 1922, s. 337); (el-Kalkaşendî, Ty, s. 6/231).

Dile getirdiğimiz bu örnekler, giriş bölümünün kurgusunu bizlere sunmaktadır. Ancak kâtipler, giriş bölümündeki bu kurgunun tamamına veya bir kısmına riayet etmeyebilmektedirler. Bazen de öğeleri atlamakta ya da öğelerden birini öncelemekte veya sonraya bırakmaktadırlar. Yahut giriş bölümü olmaksızın doğrudan konuya girebilmekte ya da kâtipler mektuplara Kur'an ayetleriyle yahut da şiirden bir beyitle başlayabilmektedirler.

\section{Sunum veya Ana Konu:}

Burası kendisi dolayısıyla mektubun yazıldığı ya da kurgulandığı bölümdür. Eleştirmenler bu bölümde hem anlamsal çerçevenin çizilmesinin zorluğuna ve hem de içerikteki konuların sınırlandırılmasındaki zorluğa dikkat çekmektedirler. Zira İbni Halef elKatib'in de dediği gibi "anlamlar amaçlananın dışına doğru yaygınlaştırılabileceği gibi sonsuz olarak da uzayabilmektedir”. Bu bölümde risalenin amac1, konu bütünlügünden ortaya çıkan kasıt, mantıksal düzen, içeriği doğru kullanma sanatı, alıntı yapma ve kullanılan delillerle birlikte kâtibin delil getirme ve gerekçelendirme yeteneği, kültürel düzeyi ve sözün manaya uygunluk sunması ön plana çıkmaktadır. Buna göre her bir risalenin içeriği konu ve risalenin kimin tarafından gönderildiği bakımından diğer risalelere göre farkll11k arz etse de bir makamdan belli bir amaç için yazılan risalenin ihtişamlı olması, konusunun bölümlendirilmesi ve konu bütünlüğüne dikkat noktasında kâtipler oldukça hırslı davranmışlardır (el-Kâtib, 2003, s. 80).

Bir başka bakımdan da bu bölüm giriș ve sonuç bölümleri arasında yer aldığı için risalenin en önemli bölümüdür. Çünkü bu bölümde katip düşüncelerini serdetmeye ve açmaya koyulur. Bunun yanında söz içerisinde detaylandırma ve çeşitli sanatsal üslupları kullanmadaki becerisini ortaya koyar.

\section{Sonuç:}

Risaleleri sonlandırma ve sanatla süsleme noktasında katiplerin üslubu oldukça çeşitlidir. Çünkü risalenin bu bölümü kulaklarda en son kalan bölümü olduğu için risalenin diğer bölümlerinden farklı olarak zihinlerdeki kalıcılığı da daha farklı olabilmektedir. Kâtiplerin prensipleri arasında risalenin duaya eşlik eden bir selamla sonlandırılması bulunmaktadır. Bazen de sözü sonlandırma Kur'an ayetleriyle, hamdeleyle ve sonrasında da Peygambere salat ile veya risalenin konusuyla uyumlu çeşitli şiirlerden beyitlerle olabilmektedir (el-Kalkaşendî, Ty, s. 6/232 ve 267).

İşte risalelerin genel hatlarıla temel kurgusu bu şekildedir.

\section{Ahmed b. Yusuf ve el-Hamîs Risalesi}

Abbasiler dönemi, ulaştığı yüksek düzey bakımından düzyazı sanatının altın çağ1 kabul edilmektedir. Bu dönemin bayraktarlığını yapan kişileri ele alan çok çeşitli araştırma ve çalışmalar bulunmaktadır. Bu araştırma ve çalışmalarda ele alanın edebi düzyazı, bilimsel düzyazı, felsefi düzyazı ve tarihi düzyazı alanları olduğu göze çarpmaktadır. Zira İbnu'l-Mukaffa, Sehl b. Harun, el-Cahız ve daha birçok isim bu alanda oldukça başarılı görülen isimlerdir (Dayf, Ty, s. 121); (Aytaç, 1991, s. 1-14). Ufkun karanlık tarafında kalıp da görünmeyen düzyazı bayraktarları da ismi anılan kişilerden pek de geride kalmamaktadırlar. Bunlardan bir kısmı isim olarak her ne kadar değerli olsalar da şöhretleri gözlerden uzaktadır. Ahmed b. Yusuf da bunlardan biridir (el-Cehşeyârî, 1938, s. 304).

\section{Ahmed b. Yusuf:}

I Asıl ad1 Ahmed b. Yusuf b. el-Kasım el-'Ícli'dir. el-Katib lakabiyla bilinmektedir. Kûfeli olup Me'mun'un risale divanlarının başında bulunmaktaydı. Abbasiler dönemindeki kâtiplerin büyüklerinden olup 213/828 yılında Bağdat'ta vefat etmiştir (ez-Ziriklî, 1986, s. 1/272). İbnu'n-Nedim onun, çağının en belagatli kâtipleri arasında olduğunu şu ifadelerle dile getirmektedir: "Nitelikleri konusunda görüş birliği olan kitaplar: Erdeşîr'in Ahdi, Kelile 
ve Dimne, Umâre b. Hamza'nın er-Risaletu'1-Mâhâniyye'si, İbnu'l-Mukaffa'in er-Risaletu'1Yetime'si ve Ahmed b. Yusuf el-Katib'in Risâletu'l-Hamîs'i (İbnu'n-Nedîm, 2009, s. 2/391).

Kaynaklar onun yazarlığ meslek edinmiş bir aile içerisinde yetiştiğini; dedesinin ve babasının da çeşitli divanlarda kâtip olduğuna vurgu yapmaktadırlar (el-Hamevî, 1993, s. 2/560). Ahmed b. Yusuf da tabi ki yazmayı seveceği, yazının inceliklerine ve gerekliliklerine vakıf olacağ1 güzel bir ortamda yaşamıştır. Babasından ve dedesinden edebiyat, şiir ve yazarlık sanatına duyduğu sevgiyi miras olarak almıştır ( Kurd Ali, 2012, s. 212). Kraliyet işlerini ve protokolleri iyi kavramış, sonuçta zekâsı ve güçlü hafizasıyla mesleğiyle ilgili işlerde zirveye ulaşmıştır. Karakter ve fazilet bakımından şaha kalkmış olup kendisinin anılan her iki hasleti hakkında çeşitli hikâyeler anlatılır olmuştur. Adı edebiyat sahasında konuşmacı ve şair olarak geçmektedir. Sözündeki değer, dilindeki sadelik ve hat yazısındaki zarafetiyle nitelendirilmiştir (el-Bağdâdî, 2001, s. 6/463). Neşeyi ve eğlenceyi sevmesiyle tanınmış olup çeşitli meclisleri vardı (et-Tevhîdî, 2011, s. 3/333). Abdulhamid b. Yahya elKatib onu görmüş ve yazısını güzelleştirmesine yarayan yönlendirmelerde bulunmuştur (elBağdâdî, 2001, s. 6/463). Bütün bunlar, gerçekten yetenekli bir yazar olması için ona uzmanlık, deneyim araçları, kültür ve zevki sağlamış; nihayet uzmanlığındaki parlak şöhreti insanlar arasında yayılmış ve Me'mun'un veziri olmuştur (İbnu Abdi Rabbih, 1983, s. $5 / 376)$.

Emin ile Me'mun arasında çıkan fitne olayında Me'mun'a bir yazı yazınca yıldızı parlamış ve bu yazısında Me'mun'un halifelik meselesinde daha haklı olduğundan bahsetmiştir. Me'mun da onun yazısını çok beğenmiş, onu kendisine hem vezir hem de baş kâtip yapmıştır. Me'mun'a yazdığı yazı şöyledir:

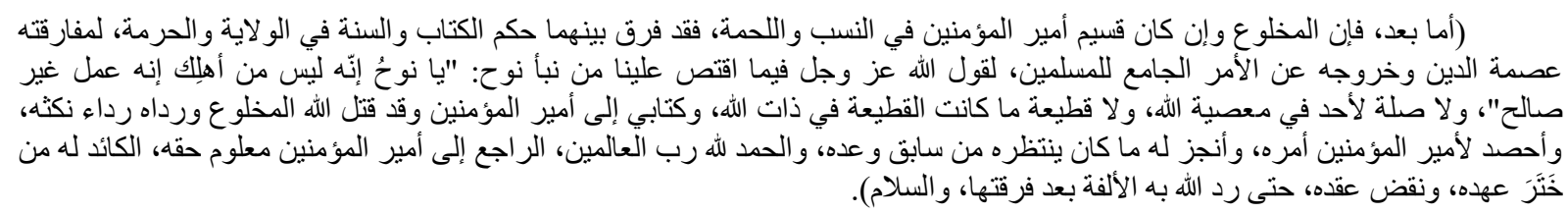

"İmdi, devrik kişi her ne kadar soy ve can bakımından müminlerin emirine hissedar olsa bile dini dokunulmazlıktan uzak olduğu ve Müslümanların genelinin hükmünün dişına çıktığı için kitap ile sünnet, yöneticilik ve dokunulmazlık bakımından artık ikisini birbirinden ayırmıştır. Nitekim Allah azze ve celle bizim için Nuh peygamberden örnekle haber vermektedir: 'Ey Nuh! O, artık senin ehlinden değildir! Onun kurtulmasını istemen de doğru değildir!' Allah'a isyanda olan kimse ile hiçbir bağ kalmamış ve esasen Allah katında kopmuş olan bağ koparan da yoktur. Allah devrik kişiyi hem bastırmış ve hem de ona anlaşmayı bozanın cübbesini giydirmiş; onun işini bitirmeyi müminlerin emirine nasip etmiş ve kendisine de daha önce sözünden dönenin beklediği akıbeti hazırlamıștır. Hamd, alemlerin Rabbi'nedir. Müminlerin emirine bağlı kalanın da hakkı bellidir. Ama ahdini bozanın başına gelen ne ise aldatan kişinin başına gelecek olan da odur. Ta ki Allah, ayrılığından sonra ayrıldığı kişiyle tekrar yakınlık kurmayı nasip edinceye kadar bu böyledir. Vesselam" (el-Cehşeyârî, 1938, s. 304).

Ahmed b. Yusuf bu mektupta, kardeşiyle çekişen Emin'in isyankârlığını ve Müslümanların oybirliğiyle aldığı kararın dışına çıktığını öne çıkarmakta. Emin'in kendi cezasını bizzat kendisinin kesmiş olduğu ve bir daha hem yönetim ve hem de merhamet ortamı asla kendisine dönmeyeceği için bu felaket bağlamında Emin'in isyankârllğı ile Nuh'un oğlunun isyankârlığı arasındaki ilişkiyi betimlemektedir. Zira Emin, kardeşi Me'mun'un veliaht olduğuna dair babasına verdiği sözü tutmayarak ailenin dışına çıkmış ve böylelikle de layık olduğu karş1lığ1 görmüştür.

\section{Risaletu'1-Hamîs:}

Risaletu'l-Hamîs'e baktığımızda kâtibin özenle ve özel çabasıyla yazması gerektiğini görürüz. Nitekim her Abbasi halifesi yönetime geçtiğinde yazıya geçirilmesi gerekli olan siyasi risalelerin en önemlilerinden birisi Risaletu'l-Hamîs'tir. Risalenin konusu ise Abbasi propagandasına katkıda bulunmak, mevcut halifenin desteklenmesi, hakkındaki öykülerin tek tek anlatılması, başarılarının tanıtılması ve halifenin kendi ailesi içerisinde halifeliği en fazla hak eden kişi olduğunun açıklanmasıdır. İlk olarak Risaletu'l-Hamîs yazan kişi, fasihliği ve kaliteli yazılarıyla meşhur es-Seffah ve Mansur'un kâtibi Umâre b. Hamza'dır (Dayf, 1966, s. 468); (İbnu'n-Nedîm, 2009, s. 2/366).

İşte bu Risaletu'l-Hamîs Abbasi halifelerinin başa gelmesi sırasında yazılmakta olup içerik olarak Abbasi Halifeliği için tanıtım broşürdür. Bu risale, Abbasoğullarının taraftarı 
olan Horasan halkından kimselere okunurdu. Bu risalenin ne sebeple Risaletu'l-Hamîs adıyla anıldığına ilişkin net bir açıklama bulunmamaktadır. Ancak ihtimaller arasında en güçlü olanı, bunun anılan ordunun niteliklerinden biri olması veya ordunun gücüne işaret ediyor olmasıdır ${ }^{3}$ (İbn Manzûr, Ty, s. 6/70).

İște Risaletu'l-Hamîs de bu noktada en önemli olabilecek bir risaledir. Zira bu risale türü yeni halife tahta geçtiğinde devlete başkaldırmaya ve isyana en yatkın olan Horasan halkına yazılmaktaydı. Çünkü Horasan halkı halifeliği ve sultayı ele geçirme niyetlerini açıkça dile getiriyordu. Hilafeti kimin hak ettiği konusundaki çekişmelerde kendilerine hak veriyorlardı. Abbasi devletinin kurulmasındaki en önemli payın kendilerinin olduğunu söylemek suretiyle Abbasi devletinin kurulmasında Ebu Müslim el-Horasani'nin katkısının olmasiyla kibirleniyorlard1.

Ahmed b. Yusuf bu risaleyi Me'mun'un halifeliğe geçmesi üzerine Horasan halkına yönelik olarak yazdığında şöyle demiştir (Safvet, 1938, s. 3/317-334):

(من عبد الله الإمام المأمون أمير المؤمنين إلى المبايعين على الحق و الناصرين للاين، من أهل خراسان وغير هم من أهل الاسلام: سلام

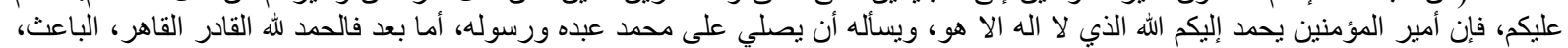

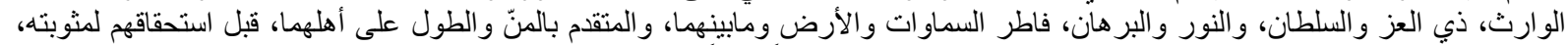

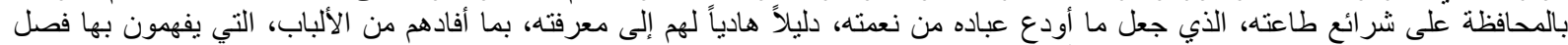

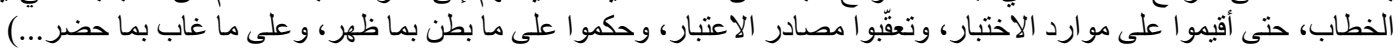

“Allah'in kulu ve müminlerin emiri İmam Me'mun'dan Horasan halkına ve dahi başka yerlerden ve İslam ehlinden olup hak üzere biat eden ve dinin yardımcıları olanlara hitaben! Selamun aleyküm! Müminlerin emiri sizden dolayı tek tanrı olan Allah'a hamd etmekte; O'ndan kulu ve elçisi olan Muhammed'e salat dilemektedir. İmdi! El-Kahir, el- Kadir, elBais, el-Varis, izzet ve hükümranlık sahibi, nur ve burhan sahibi, gökleri, yeri ve ikisinin arasındakileri ortaya çıkaran, itaat yollarını henüz muhafaza etmedikleri halde kullarına sevaplarını vermekten kaçınmayan ve bu haldeyken göklerin ve yerin ehlinin minnetlerini kendisine sunduğu Allah'a hamd olsun. O ki şu haldeyken gönüllerine fayda veren ve kendisinin tanınmasına yarayan bir kılavuz ve delil olması için kullarından nimetini esirgememiş ki böylelikle hele bir deneyimli kimselerin peşine düşsünler ve muteber kaynakları izlesinler! Bu deneyimli kimseler ve muteber kaynaklardır ki gizliye karşı açığa çıkanla ve dahi uzaktakine karşı da hazırda olanla hüküm vermişlerdir" (Safvet, 1938, s. 3/318).

Ahmed b. Yusuf, risalesine Allah'a hamd ile başlamış ve mükemmel bir özen göstermiştir. Sonra sözü Abbasilerin halifelikteki hakkına getirmiş, bunu da onların Allah elçisine olan yakınlıklarına bağlamıştır. Dolayısıyla Allah elçisine mirasçı olmaya daha müstahak olduklarını açıklarken şu sözleri söylemiştir:

$$
\text { بطاعته، فقال: (أطيعوا الله و أطيعوا الرسول الور أثة في محكم تنزيله قوله تعالى: (وأولوا الأرحام بعضهم أولى بعض في كتاب الله). ثم قرن طاعتهم }
$$

“Onları (Abbasoğullarını) mirasta haklı kılan husus Allah'ın indirdiği Kur'an'daki şu buyruğudur: 'Aralarında kan bağı bulunanlar Allah'ın kitabında (mirasçılık bakımından) birbirlerine diğer müminlerden ve muhacirlerden daha yakındırlar.'4 Sonra da Allah onlara itaati kendisine itaate yakın saymış (Safvet, 1938, s. 3/322) ve buyurmuştur ki: 'Allah'a itaat edin, Peygambere itaat edin, sizden olan ulu'l-emre itaat edin'."5

Böylece Ahmed b. Yusuf halifelikte Abbasilerin haklı olduklarına delil getirmektedir. Abbasilerin propagandasını yapmakta sonra da uzunca Me'mun'u överek kardeşi Emin'le aralarında geçeni şu sözlerle açıklamaktadır:

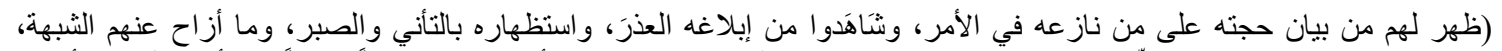

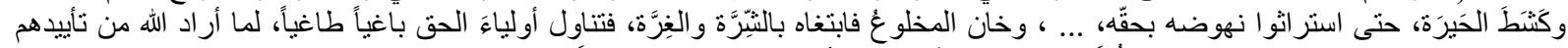

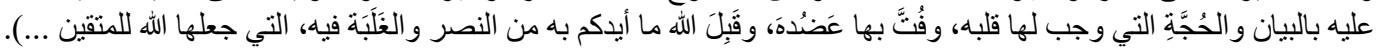

"Onlara, yönetime gelme hususunda çekiştikleri kişilere karşı delillerini getirme imkanı sunulmuş, iletimde bulunulduktan sonra ileri sürecekleri mazeretlerini belirtmeleri ve durumlarını açıklamaları için teenni ve sabır gösterilmiştir. Şüpheleri ve şaşkınlıkları giderilmeye çalışılmış ve iddia edilen hakları karşılıklı olarak elde etme çabası güdülmüştür... Ancak ne var ki devrik kişi ihanet etmiş, tahtı zorbalık ve ansızın elde

\footnotetext{
${ }^{3}$ el-Hamîs kelimesiyle kastedilen el-Ceyşu'l-Cerrâr adlı birliktir. Güçlü orduya işaret ederek beş bölükten oluştuğu için bu adla adlandırılmıştır. Bu bölükler: Öncü, merkez, sağ, sol ve artçı birliklerdir.

${ }^{4}$ Ku'an- Kerim, Ahzab Suresi, 33/6.

${ }^{5}$ Ku'an- Kerim, Nisa Suresi, 4/59.
} 
etmeye çalışmış, Hak sahiplerini de yoldan çıkmış azgınlar olarak değerlendirmiştir. Artık Allah, bunları gerekli açıklama ve delillerle ona karşı başarılı kılınca da tahttan indirilmesi gereği doğmuştur. Nihayet gücü kırılmış ve Allah sizin için peşinde olduğunuz kişinin zafer ve galibiyetini tıpkı takva sahiplerinin işini makbul saydığı gibi makbul saymıştır..." (Safvet, 1938, s. 3/324).

Tabii ki öte yandan da devlet taraftarlarının, öncelikle Abbasi devletinin kurulmasındaki katkılarını ikinci olarak da Me'mun'un zaferindeki katkılarını övmek gerekiyordu. Buna bağlı olarak Ahmed b. Yusuf risalede Horasan halkının faziletini övmekte, hasletlerini saymakta ve Abbasilerin zaferindeki katkılarını dile getirmektedir:

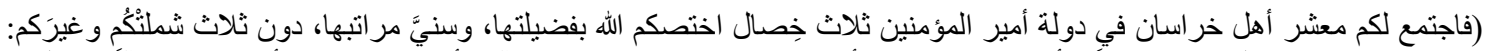

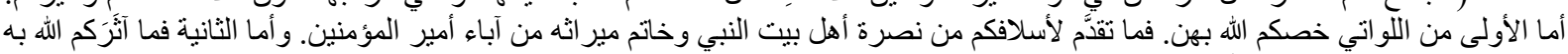

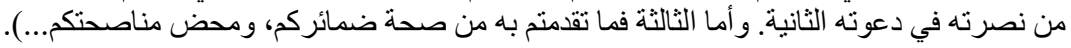

“Ey Horasan halkı! Müminleri emirinin devleti nezdinde Allah'ın size özgü kıldığı ve mertebesi yüce olan üç özelliğiniz bulunmaktadır. Bunlar size ve sizin gibilere özgü! Allah’ın size özgü kıldığı özelliklerin ilkine gelince sizden öncekilere, Peygamberin ehli beytine yardımcı olmak nasip olmadığı gibi müminlerin emirinin atalarından miras kalan mühre yardımcı olmak da nasip olmamıştır. İkincisi ise müminlerin emirinin ikinci çağrısında yardım etmek için Allah sizi seçmiştir. Üçüncüsü ise siz, yaptığınızı sadece vicdanlarınızın bütün temizliğiyle ve verilen öğüdü tutarak yaptınız!...” (Safvet, 1938, s. 3/324).

Ardından da Horasanlıların kendisine destek olması için sözlerini devam ettirmiş, verdiği öğütte düşmanlarla mücadele etmek ve de Me'mun'a teşekkür etmek için ne yapmaları gerektiğini açıklamıştır:

$$
\begin{aligned}
& \text { (و إلى الله يرغب أمير المؤمنين في إعانته على صالح نيته، وتبليغه منتهى سؤله، و غاية همه، في إعز از دينه، و إذلال من صداء صد عن سبيله، }
\end{aligned}
$$

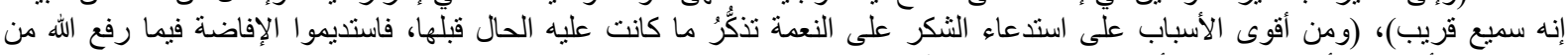

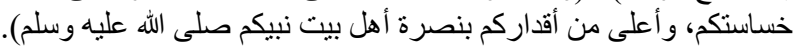

"Müminlerin emiri niyetini bütün temizliğiyle koruyabilmesi, isteğinin sonuna kadar yerine gelmesi, amacına erişmesi, dinini aziz kılması, O'nun yolundan alıkoyanları rezil etmesi hususunda Allah'in yardımını dilemektedir. O, en iyi şekilde kulunu duyan ve kuluna yakın olandır." "Teşekkür etmenin en güçlü sebeplerinden biri de daha önceleri vaziyeti ne olduğunu hatırlayıp ona göre nimete şükretmektir. Daha önce düştüğünüz alçaklığı artık Allah'in sizden kaldırması ve Peygamberinizin (sav) ehl-i beytine yardım ettiğiniz için değerinizi yüceltmesi nedeniyle Allah’a şükrünüzü artırınız!" (Safvet, 1938, s. 3/326).

Daha sonra da mektubuna Horasanlıları birlik ve beraberlik içinde olmaya çağırmak suretiyle devam etmiştir. Onları ayrılık ve bölünme tehlikesine karşı uyarmaktadır. Kendilerine o zamana kadar verilen ihsanlara devam edileceği sözü de vermiştir:

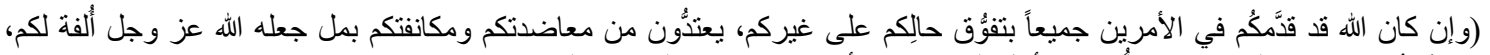

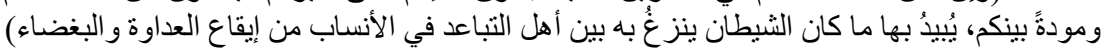

"Eğer Allah iki hususta hepten sizi öne çıkarsaydı başkaları nezdindeki statünüz yükselse bile Allah'ın size bahşettiği yakınlık ve aranızdaki sevgiye duydukları hasetten kalplerinin daralması sebebiyle yardımınızı ve desteğinizi kabul etmezlerdi. Halbuki Allah, şeytanın düşmanlık ve kin sokmak suretiyle zürriyetleri ayrı olan kavimler arasına yerleştirdiği ayrılığı sevgi vasıtasıyla ortadan kaldırmaktadır" (Safvet, 1938, s. 3/325).

Ahmed b. Yusuf Ma'mun'un diliyle onlara kıymetlerinden dolayı birtakım ibretli sözler ve öğütler yöneltmiş ve demiştir ki:

$$
\text { ( و اعلموا أن أمير المؤمنين متفقٌِّ من تثقيفكم وتقويمكم، على صالح الأدب، ومحمود السيرة، مالا يتفقد به من سواكم...). }
$$

"Ve biliniz ki müminlerin emiri gayet edepli bir şekilde sizin ne kadar aydınlandığını, ne kadar yeterli olduğunu, yaşantınızın ne kadar övgüye değer olduğunu, başkalarında görmediği şeyi sizden görmek ve anlamak istemektedir" (Safvet, 1938, s. 3/331).

Devamında müminlerin emirinin Horasanlıları başkalarına üstün tutmaya yönlendiren sebepleri açıklamaktadır:

$$
\text { إنكم أولى بحسن الطاعة وسر عة الإجابة، للطف محلّكم، وقرب مكانكم عند أمير المؤمنين). }
$$

"Sizler ki müminlerin emirine mevkiinizin yakınlığ1 ve konumunuzdaki zarafetinizle birlikte itaati güzelce sergilemede ve yardıma hızlıca yetissmede en önde gelmektesiniz" (Safvet, 1938, s. 3/331). 


\section{Risaletu'1-Hamis'teki Bazı Fikirsel Ve Betimsel Özellikler ve Ahmed B. Yusuf'un Üslubu:}

Risaletu'l-Hamîs, Cemheretu Risaletil-Arab adlı kitapta yaklaşık on beş sayfa tutmaktadır. Okunduğunda kelime seçkisindeki denge ve bazen de seci kullanımındaki genişlik fark edilmektedir. Şevki Dayf'ın de dediği gibi karşımıza şöyle bir görüntü çıkacaktır: "Anlamda açıklık, delil bolluğu, sözü çoğaltma, hitap yöntemiyle genişçe açıklama. Üslubu güzel; dili de arı duru, kolay ve anlaşılır bir dildir. Paragrafları gayet düzenli olup içerisinde müstehcen olmayan kafiyeler vardır" (Dayf, 1966, s. 469).

Ahmed b. Yusuf'un yazılarında en önde gelen özellikler arasında Kur'an ayetlerinden delil getirmek ve siyasi olayları delillendirmek için Kur'an'dan alıntı yapma olayıdır. Bir başka yönüyle de Ahmed b. Yusuf seci’i kullanmakta üstün bir üsluba sahiptir. Bunu da sadece sözün bazı yerlerde uzaması durumunda kullanmaktadır. Seci kullanması süsleme amacına dönük olup bu durum Risaletu'l-Hamîs'te gayet açıktır ( Kurd Ali, 2012, s. 213).

Risaletu'l-Hamîs'e kompozisyon üslubu yönünden baktığımızda Ahmed b. Yusuf'un kompozisyon düzeninde birçok üsluba dayandığını görürüz. Zira onun üslubunda kompozisyondaki söylemin ve anlamın gücü oldukça belirgindir. $\mathrm{O}$, bu risalesini Horasan halkına yazarak öğüt vermiş ve onları devlete tutunmaya teşvik etmiştir. Bu münasebetle de risalenin söyleminin içeriğine uygun olması gerektiği açıktır. Nitekim Ahmed b. Yusuf bu risalesinde emir ve nehyi kiplerini çokça kullanmış, bunun yanında uzun açıklamalar yapmıştır. Ayrıca sözde ayrıntıya ve uzatmaya meyilli davranmış ve birçok yerde de sözlerine Kur'an ayetlerinden deliller getirmiştir.

Eğer retoriğin temel kuralına gidersek karşımıza Arapların "sözün en hayırlısı az ve öz olanıdır" atasözü çıkmaktadır. Ancak bu temel kural bu risaleyle uyuşmamaktadır. Çünkü bu risale hem kendine özgü rengiyle ön plana çıkmakta hem de siyasi hassasiyet niteliğine sahiptir. Zira bu risale, devletin genel tebaaya yönelik hazırladığ 1 risalelerden farklı olarak özel bir kesime yöneliktir. Risale başka bir kesime değil de sadece Horasan halkına özgüdür. Dolayısıyla da diğer risalelerden farklı olarak siyasi propaganda karakteri ve diplomasi dili özelliği taşımaktadır. Böyle bir karakter taşıdığı için de kâtibin diğer risalelerdekinden daha farklı bir dikkat göstermesi, söylemde seçici olması ve cümlelerde de özenli davranması gerekmektedir. Bunun yanında yine kâtibin Kur'an'dan alıntı yaparken ayetlerin sözün sadediyle münasip olması için incelikli bir yaklaşım sergilemesi gerekir. Ayrıca bu risalede ön plana çıkan hassasiyete baktığımızda kâtibin sözü uzatmasının ve ayrıntılara girmesinin gayet doğal olduğunu görürüz. Zira kâtip, yazısında ve kompozisyon düzeninde hünerini sergileme hususunda oldukça hırslıdır. Bundan sonra da doğal olarak kompozisyon içerisindeki sözü uzatma ve ayrıntıya girme niteliği belirginleşmektedir.

Devlet bürokrasisi açısından olaya baktığımızda da görmekteyiz ki Ahmed b. Yusuf belli kural ve kanunlara göre ilerlemekte ve bunların dışına çıkmamaktadır. Nihayetinde kâtip, halife hazretlerinin yanında sadece bir memur olduğu için halifenin divanında olması münasebetiyle kanunlara uyması gerekecektir. $O$, yazısını halifenin dilinden yazmakta olduğu için divan protokolüne uyması bir zorunluluktur. $\mathrm{Bu}$ protokol, kâtibe, hem kanunlara uyması gerektiğini ve hem de bu kâtip Ahmed b. Yusuf'un bizzat kendisi olsa bile kanunları işletmesi gerektiğini hatırlatır ( Kurd Ali, 2012, s. 213). Çünkü burada siyasi birtakım işler söz konusu olup bu işler devlete özgü işlerdir. Bu siyaseti dillendirecek olan da siyasetin çerçevesini çizen kişidir. Buna göre Ahmed b. Yusuf'un divandaki bir kâtip gibi davranarak konuya bağlı kalması ve asla konu dışına çıkmaması gerekmektedir. Ancak bütün bunlarla birlikte bu risalenin kompozisyonuna, edebi yönüne, fikri ileri sürme üslubuna ve diğer sanat üsluplarının kullanılmasına özgünlüğünü kazandıran ise kâtibin kendisidir.

\section{SONUÇ:}

Son olarak; yazışmanın insanlık tarihi kadar eski olduğunu söyleyebiliriz. Arapların da yazı yazmaya ilgi duyması da çeşitli sebeplerden dolayı olmuştur. İslam'ın ilk ortaya çıkışı yazışmaları da beraberinde getirmiştir ve zamanın ilerlemesiyle bir sanata dönüşmüştür. Daha sonrasında bu sanat Emeviler döneminde gelişmiş ve şekillenmiştir. Risale kültürü, o zamanın yaşam şartlarını yansıtan siyasi bir karakter kazanmıştır. Abbasiler döneminde ise kalkınma ve gelişmenin zirvesine ulaşılmış ve sonuçta yazı yazma sanatı edebi ve sanatsal rengini kazanmaya başlamıştır. Bu dönemde kâtipler süslü sözler kullanmaya, ssekle ve diksiyona özen göstermişler bununla birlikte araç ve içeriği de ihmal etmemişler; bunlara uygun olarak içeriğe ve konulara zenginlik katmışlardır. 
Genel olarak Abbasiler dönemindeki kâtiplerin Arap kültürüne hizmet etmede çok önemli katkılarının olduğunu görmek mümkündür. Zira kâtiplerin yazı üslupları hem düşünme biçimindeki yüceliğe hem de ifadelendirmedeki güzelliğe dayandığ i için adına yönetim dili diyebileceğimiz çift yönlü bir dili kurgulayabilmişlerdir. Bu dil, hükümdarın emir ve amaçlarını yorumlayabilmeyi hedefleyen bir dildir. Ancak aynı zamanda kelimenin tam anlamiyla Arap belagatine dayanan bir sanat dilidir. Kâtiplerin siyasi risalelerinin, o dönem şartlarında devletin lisan-1 hali olduğu kadar Abbasi rejiminin meşruiyetinin savunulmasında da önemli bir rol oynadığını söylemeye bile gerek yoktur. Bu risaleler, modern çağda devletin üst makamlarının yayınladığı; propaganda ve bildiri amaçlı yayınlara büyük oranda benzemekte olup yayının bu türü, günümüzde resmi gazetenin bile yerini tutmaktadir.

Sözün özü, kâtiplerin siyasetle ilişkisi sıkı bir ilişkidir. Çünkü kâtipler hem devletin aldığ1 pozisyonun dili olan hem de devletin siyasetini ifadeye döken kimselerdi. Yüksek konumları itibarılya devletin siyasetinde inkâr edilemez bir etkileri olduğu gibi yönetim işlerini etkiledikleri de olmaktaydı. Hatta öyle ki içlerinden uyanık olan bazıları vezirlik makamına bile çıkmaktaydı. Onlar, siyasi düşünceleri sultanın ve devletin genel siyasetinin yörüngesinde dönen kimselerdi.

\section{Kaynakça}

Kurd Ali, M. (2012). Umerâu'l-Beyân. Kahire: Mektebetu's-Sekâfeti'd-Dîniyye.

Aytaç, B. (1991). Abbasi Devrinde Nesir ve al-Harîrî. Ankara Üniversitesi Dil Tarih ve Coğrafya Fakültesi Dergisi, 35(1), 1-14. 
Azimli, M. (2008). Abbasiler Dönemi Muhammed en-Nefsu'z-Zekiyye ve Kardeşi İbrahim'in İsyanı. Din Bilimleri Akademik Araştırma Dergisi, 8(3), 55-74.

Beyyûd, Hüseyin. (1996). er-Resâilu's-Siyâsiyye fi'l-Asri'l-Abbâsiyyi'l-Evvel. Dimaşk: Menşurât Vezâretu's-Sekâfe.

Bozan, O. (2014). Taberistan Emiri Mâzyâr b. Kârîn'in Abbasi İdaresine İsyanı. Şarkiyat İlmi Araştırmalar Dergisi, 6(11), 73-93.

Çelik, S. (2006). Abbasiler Döneminde Hurremiyye Mezhebi Ve Babek İsyanı. Balıkesir Üniversitesi Sosyal Bilimler Enstitüsü Dergis, 9(15), 95-106.

Dayf, Ş. (1966). Târîhu'l-e,Edebi'l-Arabî, el-Asru'l-Abbâsiyyi'l-Evvel. Kahire: Dârul-Maârif.

Dayf, Ş. (Ty). el-Fennu ve Mezâhibuhû fi'n-Nesri'l-Arabî. Kahire: Dâru'l-Meârif.

el-Bağdâdî, E.-H. (2001). Târîhu Medîneti's-Selâm (Târîhu Bağdâd). (B. A. Ma'rûf, Dü.) Beyrut: Dâru'l-Ğarbi'l-İslâmî.

el-Cehşeyârî, M. (1938). Kitâbu'l-Vüzerâi ve'l-Küttâb. (M. es-Sakka, Dü.) Kahire: Matbaatu Mustafa el-Bâbî el-Halebî.

el-Hamevî, Y. (1993). Mu'cemu'l-Udebâ İrşâdu'l-Erîb ilâ Ma'rifeti'l-Edîb. (İ. Abbâs, Dü.) Beyrut: Dâru'l-Ğarbi'l-İslâmî.

el-Kalkaşendî, A.-A. (Ty). Subhu'l-A'şâ. Kahire: Dâru'l-Kütübi'l-Mısriyye.

el-Kâtib, A. b. (2003). Mevâddu'l-Beyân. (H. S. ed-Dâmin, Dü.) Şam: Dâru'lBeşâir Mektebetu'l-Arab.

el-Muberrid, E.-A. M. (1997). el-Kâmil. (M. A. ed-Dâlî, Dü.) Beyrut: Muessesetu'r-Risâle.

es-Sûlî, E. (1922). Edebu'l-Küttâb. (M. B. el-Eserî, Dü.) Kahire: el-Matbaatu's-Selefiyye.

et-Taberî, E. C. (Ty). Târîhul-Umemi ve'l-Mulûk (Târîhu't-Taberî),. (E. S. el-Kermî, Dü.) Riyad: Beytu'l-Efkâri'd-Devliyye.

et-Tevhîdî, E. H. (2011). Kitâbu'l-İmtâ' ve'l-Mu'ânese. (H. H. et-Taîmî, Dü.) Beyrut: elMektebetu'l-Asriyye.

ez-Ziriklî, H. (1986). el-A'lâm. Beyrut: Dâru'l-İlm li'l-Melâyîn.

Ferrûh, Ömer. (1981). Târîhul-Edebi'l-Arabî. Beyrut: Dâru'l-İlm li'l-MelâyÎn.

İbn Haldun, V. (2004). el-Mukaddime. (t. A. ed-Derviş, Dü.) Dimaşk: Dâr Ya'rub.

İbn Manzûr, C.-İ. (Ty). Lisânu'l-Arab. Beyrut: Dâru Sâdir.

İbnu Abdi Rabbih, A. b. (1983). el-İkdu'l-Ferîd. (A. et-Terhînî, Dü.) Beyrut: Dâru'l-Kutubi'lİlmiyye.

İbnu'l-Esîr, D. e.-F. (1939). el-Meselu's-Sâir fî Edebi'l-Kâtibi ve'ş-Şâir. (M. M. Abdulhamid, Dü.) Kahire: Mektebetu'l-Arab.

İbnu'l-Esîr, D. e.-F. (Ty). el-Meselu's-Sâir fî Edebi'l-Kâtib ve'ş-Şâir. (A. e.-H. Tabbâne, Dü.) Dâr Nahdatu Misır.

İbnu'l-Esîr, M. e.-Ş. (1987). el-Kâmil fi't-Târîh. (M. Y. ed-Dekkâk, Dü.) Beyrut: Dâru'lKutubi'l-İlmiyye.

İbnu'n-Nedîm, M. (2009). Kitâbü'1-Fihrist. (E. F. Seyyid, Dü.) Londra: Müessesetü'1-Furkân.

Nassâr, H. (2002). Neş'etu'l-Kitâbeti'l-Fenniyyeti fi'l-Edebi'l-Arabî. Kahire: Mektebetu'sSekâfeti'd-Dîniyye.

Safvet, A. Z. (1938). Cemheretu Resâili'l-Arabi fî Usûri'l-Arabiyyeti'z-Zâhire. Beyrut: elMektebetu'l-İlmiyye.

Türk, O. (2017). Türkçe Öğretmenlerinin Konuşma İlgileri Ve Sınıf İçinde Kullandıkları Konuşma

Dili Üzerine Bir Araştırma. Turkish studies, 12(6), 783-798.

Türk, O. (2019). Osmanlı Döneminde Kıbrıs’ta Basının Yeri. Dicle Üniversitesi Sosyal Bilimler

Enstitüsü Dergisi (DÜSBED), 11 (22), 281-294.

Zeydân, Corci. (Ty). Târîhu Âdâbi'l-Luğati'l-Arabiyye. İskenderiye: Dâru'l-Hilâl. 